\section{Pandemic profiteering during the second wave of Covid-19}

Published online first on November 15, 2021. DOI: 10.20529/

IJME.2021.087

Keywords: pandemic, Covid-19, profiteering, essential supplies, $P P E$

It's time for indignant citizens today to confront a new breed of shameful greed merchants

\section{— Jim Hightower}

The first wave of the Covid-19 pandemic saw us facing acute shortages of masks, personal protective equipment, and sanitisers, with even toilet paper disappearing from store shelves. But the Indian small manufacturers seized the opportunity and by the end of last year, we had enough PPE and masks to even export the surplus to other countries. Though we rationed even the lowly surgical masks, people did not hoard or black market any of these. But it gave people the knowledge of what would be required and would be in short supply if the second wave struck. And so started the pandemic profiteering business.

Medical professionals in India have never witnessed the amount of pandemic profiteering that occurred when the second wave of Covid-19 hit the country. With more than three lakh people getting infected every day, India saw a spike in profiteering in medical essentials trading on patient distress and touching a new low in the breach of medical ethics.

\section{Why did pandemic profiteering occur?}

In contrast to the first wave, no clear protocols were laid down for lockdown, quarantine or treatment to be followed, by either the Indian Council of Medical Research or the Union Health Ministry. The policy paralysis resulted in a free-for-all. The union and state governments' price cap on scarce lifesaving medicines and oxygen cylinders, with inadequate regulation, led to black marketing (1). With an increasing patient load and scarcity of hospital beds, there was panic buying of medicines and hoarding of essentials during this wave.

\section{What were the effects of pandemic profiteering?}

To list only a few examples of pandemic profiteering during the peak of the second wave: pulse oximeters, high-flow oxygen masks, oxygen cylinders and concentrators were being sold at more than ten times the normal price; private ambulances and mortuary vans were overcharging, both to ferry patients to, or bring dead bodies home from hospital. Several hospitals demanded exorbitant advance deposits for admission into intensive care units. RT PCR Covid tests that usually cost Rs 800, cost Rs 3000 at many centres. A few repurposed medicines like Remdesivir and Tocilizumab, which normally cost less than Rs 2000, were sold at Rs 40,000/vial (2). Some state governments even hiked intensive care bed charges in private hospitals (3). Panic stricken people were ready to hoard these essentials for an emergency, with no knowledge of how to use or replenish them.

Stranded by the sudden government lockdown, the poor migrant population, who were obliged to go home to their villages, had to spend exorbitant amounts to hire vehicles, or had to walk.

Funeral homes were literally the last straw to break the Covid victim's back, not only with long waiting lists but exorbitant charges for scarce wood and cremation procedures (4).

\section{Fake medicines, scams and scandals}

As if the curse of pandemic profiteering were not enough, scamsters produced spurious versions of drugs like Remdesivir, jeopardising the lives of innumerable hapless patients and depriving their desperate families of their hardearned money by online scams via WhatsApp, selling oxygen cylinders, oxygen concentrators, etc. Elsewhere, hospital authorities deliberately switched off oxygen supply in the intensive care unit to force patients to buy oxygen cylinders (5).

The crime branch of Karnataka police did arrest a few people involved in the "Covid bed allocation scam", even though on paper the beds were allotted officially through the Central Hospital Bed Management System of the Bruhat Bengaluru Mahanagara Palike.

\section{How can the system be cleaned?}

The Disaster Management Act of 2005 (6) clearly states that when it is enforced:

- $\quad$ there should be a National Plan;

- all help should be given to the states to carry out the plan;

- $\quad$ the government should make available the resources for emergency response, rescue and relief (7);

- $\quad$ sweeping powers are given to designated disaster management officers to enforce the plan and punish people acting in breach of the Act.

Unfortunately, none of these were implemented in the second wave. It was a case of complete policy paralysis with no clear direction or plan, resulting in every common man, hospital, or business, including crematoria, shamelessly making a quick buck from desperate patients. Swift and visible action with 
exemplary punishments should be meted out to black marketers, hoarders and extortionists, so that people fear doing such acts.

We have also seen extraordinary acts of sacrifice and empathy in many doctors, nurses, other healthcare workers, police and other essential services staff. So, one can see that there is still humanity and goodness left in our people. We need capable leaders to direct constructive action, reassure citizens by rapidly increasing and upgrading infrastructure, and take swift action against those spreading misinformation and panic. If this had been done in time, maybe we would not have to use the term "pandemic profiteering" today.

Kaushik Bhattacharya (corresponding author kbhattacharya10@yahoo.com), Specialist Surgery, CAPFs Composite Hospital BSF Kadamtala, Siliguri, West Bengal, INDIA; Neela Bhattacharya (neela.alen@gmail.com.), Consultant Plastic and Reconstructive Surgeon, Anandaloke Multispeciality Hospital, Siliguri, West Bengal, INDIA

\section{References}

1. Krishnan M. India's COVID crisis spawns black market for oxygen, drugs. DW. 2021 May 11[cited 2021 Nov 6]. Available from: https:// www.dw.com/en/india-covid-black-market/a-57496221

2. Gill P. Inside the treacherous black market for Remdesivir in Indiafrom private hospitals to distributors. Businessinsider.com. $2021 \mathrm{Apr}$ 23[cited 2021 Nov 6]. Available from: https://www.businessinsider.in/ science/health/news/how-remdesivir-drug-black-market-workingin-india/articleshow/82210121.cms

3. Special Correspondent. Private hospitals to get more for COVID-19 treatment in Karnataka. 2021 May 5[cited 2021 Nov 6]. Available from: https://www.thehindu.com/news/national/karnataka/privatehospitals-to-get-more-for-covid-19-treatment-in-karnataka/ article34484411.ece

4. Mishra A. After grief, exorbitant rates at UP cremation grounds worsen Covid horror for families. India Today. 2021 Apr 19[cited 2021

Nov 6]. Available from: https://www.msn.com/en-in/money/ topstories/after-grief-exorbitant-rates-at-up-cremation-groundsworsen-covid-horror-for-families/ar-BB1fNXVa

5. PTI. Agra hospital conducts 'mock drill' by cutting off oxygen supply; administration orders inquiry. First Post. 2021 Jun 9[cited 2021 Nov 6]. Available from: .https://www.firstpost.com/india/agra-hospitalconducts-mock-drill-by-cutting-off-oxygen-supply-administrationorders-inquiry-9698721.html

6. Ministry of Home Affairs, Govt of India. The Disaster Management Act, 2005. New Delhi:MHA; 2005. Available from: https://www.mha.gov.in/ sites/default/files/

The\%20Disaster\%20Management\%20Act\%2C\%202005.pdf

7. Gupta A. The need to activate the National Disaster Management Authority in pandemic times. Vivekananda International Foundation. 2021 May 18[cited 2021 Nv 6]. Available from: https:// cdn.s3waas.gov.in/s365658fde58ab3c2b6e5132a39fae7cb9/uploads/ 2018/04/2018041720.pdf 